\title{
Empowering Women-owned Businesses in the Era of Digital Transformation: A Review of the Opportunities and Challenges
}

Siti Fahazarina Hazudin, Mohamad Fazli Sabri, Mohd Aidil Riduan Awang Kader \& Maisarah Ishak

To Link this Article: http://dx.doi.org/10.6007/IJARBSS/v11-i19/11731 DOI:10.6007/IJARBSS/v11-19/11731

Received: 24 October 2021, Revised: 27 November 2021, Accepted: 10 December 2021

Published Online: 29 December 2021

In-Text Citation: (Hazudin et al., 2021)

To Cite this Article: Hazudin, S. F., Sabri, M. F., Kader, M. A. R. A., \& Ishak, M. (2021). Empowering Womenowned Businesses in the Era of Digital Transformation: A Review of the Opportunities and Challenges. International Journal of Academic Research in Business and Social Sciences, 11(19), 231-244.

Copyright: (c) 2021 The Author(s)

Published by Human Resource Management Academic Research Society (www.hrmars.com)

This article is published under the Creative Commons Attribution (CC BY 4.0) license. Anyone may reproduce, distribute, translate and create derivative works of this article (for both commercial and non-commercial purposes), subject to full attribution to the original publication and authors. The full terms of this license may be seen

at: $\underline{\text { http://creativecommons.org/licences/by/4.0/legalcode }}$

Special Issue Title: Youth and Community Wellness, 2021, Pg. 231 - 244

Full Terms \& Conditions of access and use can be found at http://hrmars.com/index.php/pages/detail/publication-ethics 


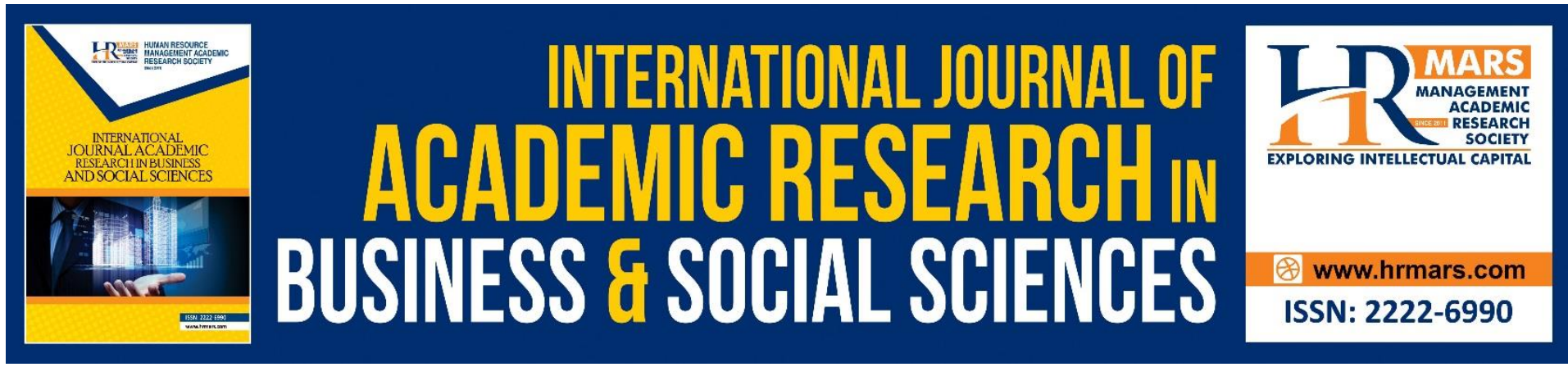

\title{
Empowering Women-owned Businesses in the Era of Digital Transformation: A Review of the Opportunities and Challenges
}

\author{
Siti Fahazarina Hazudin ${ }^{2,3}$, Mohamad Fazli Sabri'1,2, Mohd Aidil \\ Riduan Awang Kader ${ }^{3}$ \& Maisarah Ishak ${ }^{3}$ \\ ${ }^{1}$ Institute for Social Science Studies, Universiti Putra Malaysia, 43400 UPM Serdang, \\ Selangor Malaysia, ${ }^{2}$ Department of Resource Management \& Consumer Studies, Faculty of \\ Human Ecology, Universiti Putra Malaysia,43400 UPM Serdang, Selangor, ${ }^{3}$ Faculty of \\ Business and Management, Universiti Teknologi MARA Pahang, 26400 Bandar Jengka, \\ Pahang, Malaysia \\ Email: fazli@upm.edu.my
}

\begin{abstract}
This paper aimed to discuss the opportunity and challenges that are faced by women entrepreneurs in the current digital transformation development. A summary of scholarly works alongside the discussion of some important findings based on the centred issue was presented in the current paper. The analysis was focused on explaining the role of the most important digital business solution, namely social media. The major challenges of pursuing digital alternative were also discussed, varying from a traditional gender issue to emerging digital pressures. This paper provides the relevant academic explanation of the underlying requirements for creating successful women entrepreneurs in digital business, while the highlighted pitfalls can help them avoid incidentally occurrence of business failures.
\end{abstract}

\section{Introduction}

Even though, less than half women in the world owned businesses compared to their male counterparts (Hossain et al., 2019), women entrepreneurship contributes more than 50 per cent to Gross Domestic Product (GDP) in both developed and less developed countries (Ayogu and Agu, 2015). In the United States alone, women have outnumbered men in business (68 per cent) and they contribute significantly to the US economy (United States Department of Commerce, 2011). The empowerment of women in entrepreneurial activities particularly important to stimulate employment and income growth within local and domestic circumstances.

Women participation in business should not only be perceived as economically driven but more importantly, their active involvement can be an effective social factor in achieving economic growth. In addition to fulfilling their subjective self-needs, women are taking part in entrepreneurship with a noble aim to help the family, peers, and society. The significant economic role that women play in the current business landscape poses a critical challenge 
to policymakers around the world in identifying the most strategic pathways for them to become an efficient agent for socio-economic change.

Therefore, the continuous advancement in information and communication technologies should offer enormous opportunities for women to renovate their entrepreneurship practices to thrive in business and spread a desirable wealth impact on society. Nowadays, digital solutions are often adopted by businesses to achieve hike in revenues as well as create a huge potential for expanding the new market as female entrepreneurs are expected in a better position to leverage digital business transformations (Pergelova et al., 2019). A report published by US private entities (Guidant, 2019) had also revealed the impulsive rise in female-dominated businesses, namely health, beauty, and fitness (such as wellness spas, salons, and gyms) among the top five small business industries. This rise is predicted to be the result of the increasing consumerism with regard to online information sharing in social media. The utilisation of business web pages and social media platforms have become the key business activities in reaching out to a limitless number of customers, further leading to the rapid growth in sales and revenues (Jones et al., 2015; Chatterjee et al., 2020).

In support of this encouraging trend, this paper aims to explain the fundamental requirement for women-owned businesses to be empowered in the era of digital transformation. The review of academic publications in the context of business opportunities and challenges will provide insightful details on how women are viewed as future untapped economic resources and social remedy to prolonged imbalances in terms of wealth inequality, gender disparity, and family sustainability. It should also be noted that a systematic approach is employed in presenting the current review within specific keywords covering digital business, social media marketing, online business, e-business, e-marketing, and all Internet-based marketing in general.

To some extent, the analysis of past literature on different facets of prospects and vulnerabilities to the sustainability of women-owned businesses in digital era transformation can lessen the intensity of knowledge gaps and misguided experience as a result of the unprecedented changing environment. Although issues of entrepreneurship and technology have been addressed extensively, the role of women entrepreneurs has not received sufficient emphasis in the existing academic discussion. The objectives of this paper are as follows; 1 ) to understand the capability of the digital transformation in widening the windows of opportunity for women-owned businesses and 2) recognise the challenges of future digitalisation of business in order to take the advanced prescription in managing vulnerabilities. Accordingly, these two practical objectives should be able to facilitate further development of ideas in academic research and possible theoretical adjustments in the studies of entrepreneurship focusing on women.

\section{The Rise of Digital Business Opportunities}

The rapid advancement of technology has created new opportunities for sharing and developing knowledge in society and shaping the success of entrepreneurs (Tehseen et al., 2021; Oggero et al., 2021). Unlimited opportunities for business and economic development can also be afforded, especially for women entrepreneurs in establishing the business. Consequently, digital business is considered as an effective avenue to increase the potential of women in business. These opportunities have been examined by many studies in an effort to accommodate the central role of women in the economic development at the present time (Kamberidou, 2020; Krieger-Boden and Sorgner, 2018; Mishra, 2017; Maier and Nair-Reichert, 2008). 


\section{Enhance Customer Value}

In digital business, people heavily rely on the Internet for social interaction as well as to fulfil their needs. Digital business also offers women the right prospect to transform some of the traditional cultures, methods, and other barriers in establishing their businesses. This reinvention of business allows women to work more flexibly as well as interact with customers by providing them timely feedback and up-to-date information. Emails and social media platforms are employed as a medium to respond to customers' enquiries as they enable customers to get the product information promptly. This improved situation may bring about a significant impact on customer experience. According to Komunte (2015), digital business creates a sense of empowerment such that customers can easily purchase products anytime and anywhere with the use of social networks. In consequence, customers will develop closer and stronger loyalty relationship with the brands.

\section{Improve Business Process}

Digital business is utilised by women entrepreneurs across the world who have to juggle between business and family responsibilities in maintaining their business growth as well as competing more effectively. Komunte (2015) has investigated the advantages of mobile phone use among 280 women entrepreneurs who owned micro-enterprises, small-scale enterprises, and medium enterprises. The research outcome revealed that more than 75 per cent of the respondents agreed that the use of digital business facilitated women entrepreneurs to coordinate and improve the business process. Furthermore, the use of mobile internet and mobile banking in business can also reduce the mobility cost and further encourage interaction with customers (Prokopenko et al., 2020). By searching, sharing, and discussing important business information, productivity is enhanced and women entrepreneurs are also able to solve problems more quickly. Consequently, it would be much easier for a women entrepreneur to carry out the responsibilities towards her family.

\section{Attaining Financial Stability}

Traditional business methods that required extremely long hours, hard work for many years, and high cost can be bypassed completely through the application of digital business. It also assists women to attain real financial independence, increase profit, and simultaneously fulfil the desire to prioritise their family. This digital transformation enables them to generate more income by reducing operating costs (e.g. eliminating travel expenses) and reduce printing costs, especially for customers who request for receipts or coupons for returns and discounts. Research conducted by Fuad et al (2011) revealed that 29 per cent of respondents agreed that the purpose of starting a digital business is to generate self-income and extra money while working at home. The respondents in the study conducted by Hashim et al (2011) also claimed that their business sales had increased up to 40 per cent after using the online platform as the business medium.

\section{Go Global}

Social media has transformed the way in which women entrepreneurs market their products such that they are not required to commute to access more people, promote products, and establish business reputation (Beninger et al., 2016). This positive change may encourage women entrepreneurs to expand their business more vastly. According to Wally and Koshy (2014), social media acts as an alternative for a costly and time-consuming traditional marketing technique. It is highly effective in tracking customers, enhancing the product image 
as well as creates a more efficient communication between business owners and potential customers. A good-quality relationship with customers can be established and it further enables entrepreneurs to influence more customers worldwide. In addition to generating business engagement without any social pressure, social media also functions as a platform where women entrepreneurs can effectively develop their brand awareness and increase sales volume without having to mix with others (Everson, 2019).

\section{Creative Business Approach}

Digital business is a creative approach that can maximize individuals' potential, interest, and talent in enhancing their business. The variety of functions on social media platforms such as Whatsapp and Instagram can express human interaction and feelings such as liking, disliking, and sharing. These features can attract more potential customers to respond and actively inquire about the products or services. Instead of the traditional business method, women entrepreneurs choose digital business it correlates with their creative strength. Smith et al (2016) contended that women have higher entrepreneurship intention because they are more creative than their male counterparts in business. Based on the research conducted on 225 women entrepreneurs in Malaysia, Raman et al (2008) discovered that the respondents were motivated to start a business because they wanted to explore their inner talent and start doing something creative in their life. Therefore, it is deduced that women entrepreneurs can become successful in digital business by adopting technological approaches that result in higher business potential and greater creativity.

\section{Matching Personality}

Personality traits such as lower energy level, harm avoidance, risk-taking, and a higher tendency to introverts cause women to become more comfortable to run their business without having to deal directly with the outside world. Hence, digital business still allows women entrepreneurs to advertise and sell their products and services alongside having the opportunities to succeed in the business world (Cesaroni, 2017). They can also gain entrepreneurial experience, enjoy freedom, autonomy, and generate more earnings to help their family. According to Shmailan (2016), successful women entrepreneurs are optimistic and possess a high level of courage in achieving their goal. They work very hard and are able to face risks for their business growth. Thus, women entrepreneurs can build a business from home and design their own work schedule through the virtual workplace, mobile business, and the aids of digital tools. Figure 1 below summarizes the key findings on digital business opportunities for rapid development of women enterprise.

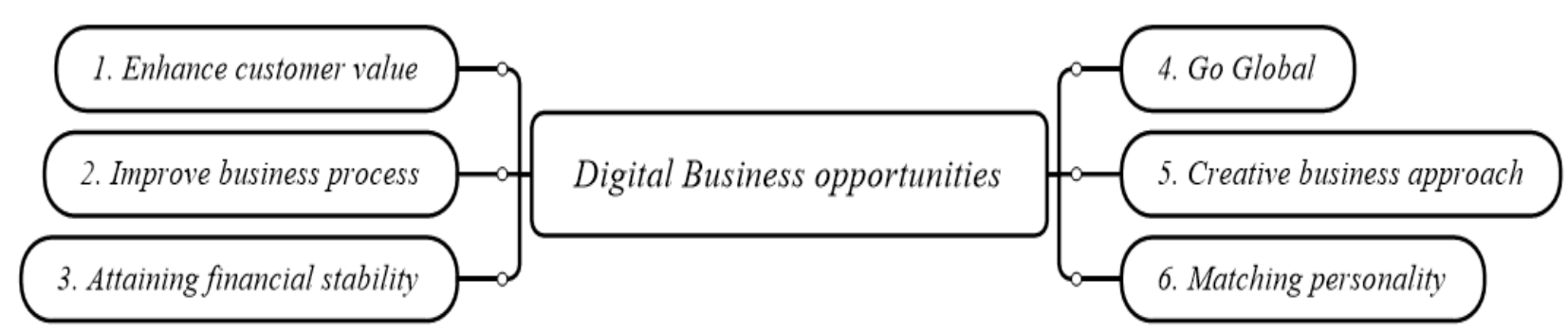

Figure 1: Mapping Digital Business Opportunities 


\section{Challenges in Empowering Women in Digital Business}

Despite the benefits of online business platform, cultivating digital practices among women entrepreneurs is rather challenging (Oggero et al., 2019). Many studies have been conducted in many countries particularly those with an emerging economy to examine the challenges faced by women entrepreneurs that are primarily related to SMEs. These countries include Turkey (Merve and Burcu, 2015), Tanzania (Kazimoto, 2014; Isaga, 2019), South Africa (Victoria et al., 2019), Saudi Arabia (Maura et al., 2018), Swaziland (Happyson et al., 2018), South Korea (Asia Pacific Women's Information Network Centre Report, 2018), South East Asia (Asian Development Bank and The Asia Foundation Report, 2018) and Malaysia (Abdul Razak and Amran, 2016; Hashim et al., 2011; Thuaibah et al., 2007; Ariffin et al., 2017; Teoh and Chong, 2014; Xavier et al., 2011; Alam and Jani, 2011; Hashim, 2012). Accordingly, the challenges that are encountered by women entrepreneurs, especially in digital business, are explored in this section.

\section{Digital Knowledge and Skill Competency}

Although the application of e-commerce will enhance the accessibility of the market, the knowledge and skills in using information communications technology (ICT) are necessary. The use of ICT is crucial in digital business and women entrepreneurs must integrate the technology in their business as well as a part of their daily responsibilities. Activities in digital business include entrepreneurs to manage their website, update product information, promote new products online, and respond to all queries every single day. Since ICT is everchanging, it is crucial that digital entrepreneurs are equipped with high digital literacy, as well as technical and online marketing skills to attract more customers. This situation also implies that these skills are essential for the success of digital business (Happyson et al., 2018; Kazimoto, 2014). Nevertheless, Merve and Burcu (2015) claimed that the use of social media in digital business poses some disadvantages including plagiarism, unidentified target audience, and unfair competition. The study also discovered that Facebook serves as the primary source for marketing communication.

Many reports associated women entrepreneurs with challenges such as difficulty in gaining skills to grow a business, in addition to the lack of skills, experiences, and marketing expertise. A report by Asia Pacific Women's Information Network Centre (APWINC) (2018) of Sookmyung Women's University investigated the main challenges faced by face to face interview of 24 women entrepreneurs. Under the supervision of the Ministry of Gender Equality and Family of the Republic of Korea, this study found that the common challenges women entrepreneurs have to face include lack of skills and experiences. These results also correlate with the report provided by the United States Census Bureau (2018) where 39 per cent of the female respondents claimed that they were lacking in marketing expertise.

In the context of Malaysia, several studies have been performed to investigate the lack of knowledge and skill among women digital entrepreneurs. Abdul Razak and Amran (2016) examined online women entrepreneurs from rural areas around Klang Valley, Malaysia and discovered that low digital literacy, limited English proficiency, and lack of online marketing skills were the barriers that rural digital women entrepreneurs had to encounter. The finding by Teoh and Chong (2014) have suggested that, common problems which need to be addressed by women entrepreneurs in SMEs sectors were mainly derived from poor social and business networking. 


\section{Public-private Partnership Supports}

In comparison to conventional businesses, it is more difficult for online businesses to obtain loans and advisory services as they are still new, especially in developing countries including Malaysia (Xavier et al., 2011; Hamdan and Hassan, 2018). In the study investigating the key factors affecting the success of 199 women entrepreneurs in the Southern Region of Malaysia, Alam and Jani (2011) revealed that family support plays a significant role towards the success or failure of women entrepreneurs in SMEs. In addition, APWINC (2018) reported that the typical challenges that women entrepreneurs had to face include the lack of mentors and coaching networks. In studying 304 women entrepreneurs who registered under PERDASAMA Malaysia, Hamdan and Hassan (2018) revealed that the difficulty to get business advice (with the mean score 3.16 out of 5) was one of the main challenges among these entrepreneurs. In another study, Anisiobi et al (2014) found that unreliable supplier specifically posed a critical problem to women entrepreneurs. Contrastingly, Thuaibah et al (2007) confirmed that only 39 per cent of the respondents in their study stated that they had a problem with their suppliers.

Victoria et al (2019) have examined the impact of ICT on self-efficacy, social capital, and empowerment in the overlooked context of 199 women micro-entrepreneurs in South Africa. This study indicated that ICT usage had a strong direct influence on self-efficacy and social capital bonding. Additionally, evidence of inadequate government support was discovered among women entrepreneurs in Swaziland and most of the women were not aware of how they could get support and funding for their businesses (Happyson et al., 2018). The result of this research is similar to that of Kazimoto (2014) where it was found that 94 per cent of the respondents agreed that government support was lacking.

\section{Financial Limitations}

In terms of the financial struggle, women entrepreneurs were typically challenged with lack of government loan and capital, as well as difficulty in getting credit from suppliers. This situation occurs due to the fact that digital business is still new in developing countries such as Malaysia. Therefore, more time is needed to prove to the bank and government that the digital business can earn profit as much as brick and mortar businesses. In the context of Malaysia, many studies have confirmed that women entrepreneurs in this country faced a financial challenge when running their businesses ( Ariffin et al., 2017; Ilhamamie et al., 2014; Wahid et al., 2021; Xavier et al., 2011).

Thuaibah et al (2007) examined the factors that influence women entrepreneurs' involvement, achievement, and failure in business. This study was performed on 215 women entrepreneurs in Johor, Malaysia. It was revealed that 64 per cent of the respondents experienced a lack of capital and 55 per cent of them stated that they faced difficulty in getting a loan from the government and private sector. Hence, it is crucial for governments to continuously provide a supportive business environment to accommodate the international growth and development of women SMEs in Malaysia (Malik et al., 2021; Wahid et al., 2021).

In the context of Tanzania, Isaga (2019) explored the challenges confronted by women entrepreneurs by distributing semi-structured questionnaires and conducting in-depth interviews with 20 research participants. The results suggested that the most serious problem faced by women entrepreneurs in Tanzania was the lack of access to finance. This finding is congruent with that of the Asian Development Bank and The Asia Foundation Report (2018) which suggested that women in South East Asia are challenged in terms of accessing finance. 
In some markets, their access is as low as one-seventh of men's access to finance. Similarly, APWINC (2018) confirmed that women entrepreneurs have limited access to finance.

\section{Cultural Barriers}

Women entrepreneurs in emerging countries play an active domestic role in their family and this condition imposes a cultural barrier associated with gender issues. In a study conducted on 31 women SME entrepreneurs from retail and service sectors in Sarawak, Malaysia, Anisiobi et al (2014) found that excess family responsibility was one of the critical challenges that women entrepreneurs confronted. Meanwhile, Abdul Razak and Jah (2016) studied the involvement of women entrepreneurs in social media. Based on three case studies, the results confirmed that women entrepreneurs who used social media for marketing and branding purposes have low participation in online business compared to men due to their hectic daily schedule in managing their family responsibilities. In more recent research, Isaga (2019) also confirmed that one of the most serious problems faced by women entrepreneurs in Tanzania included gender-related issues and social-cultural commitments.

\section{Fierce Competition}

Social media has been one of the most prominent platforms for entrepreneurs to release their new products or services into the digital market. As a result, competition has become increasingly challenging for women entrepreneurs to stay relevant in digital business (Anisiobi et al., 2014; Victoria et al., 2019). Additionally, digital women entrepreneurs in Malaysia are also facing competition from Chinese producers that enter the country market through the ecommerce platform (Utusan Malaysia, 2019). In a study conducted by Hamdan and Hassan $(2018$, ) the competition in business (with the mean score of 3.79 out of 5) was recorded as one of the main challenges for women entrepreneurs because they need to compete with male counterparts who are far more committed. As mentioned previously, Merve and Burcu (2015) confirmed that the use of social media in digital business poses some disadvantages, such as plagiarism, unidentified target audience, and unfair competition.

\section{Trust}

It is especially difficult for digital entrepreneurs to convince customers to buy their products online. Due to the feeling of insecurity when doing online transaction, i.e. involving online payment, some customers have a belief that they will be cheated by digital entrepreneurs. Based on the study of digital entrepreneurship in the context of emerging economies in Saudi Arabia, Maura et al (2018) found that only $7.5 \%$ of Saudis were willing to use credit cards online. Furthermore, the majority of the respondents stated that it is difficult to build customer trust in online selling. According to Simanjuntak et al (2020) customer trust exhibited a significant effect on customer retention suggesting that the higher the customer trusts the higher the customer retention.

\section{Policy and Regulation}

The absence of a specific policy or guideline that is related to e-commerce law poses a challenge for digital entrepreneurs when dealing with policies and regulations. A study conducted by Kazimoto (2014) which involved 50 SMEs in Tanzania confirmed that 88 per cent of the respondents agreed that they had a lack of awareness in relation to the international marketing regulations and standards. 


\section{Lack of Confidence}

The use of e-commerce has been proven to enhance the confidence of entrepreneurs in managing their business because they do not need to participate in face-to-face dealings with customers, particularly in the rural area (Hashim et al., 2011; Kazimoto, 2014). Nevertheless, in research investigating the developmental challenges associated with women entrepreneurship, Teoh and Chong (2014) found that lack of confidence was one of the critical challenges that women entrepreneurs had to encounter.

\section{Difficulties Finding the Right Employees}

Previous research has suggested that it is easier to find employees for conventional businesses compared to digital business since ICT skills are not the requirement for entrepreneurs to manage their business (Anisiobi, 2014; Xavier et al., 2011). A study performed by Thuaibah et al (2007) in examining the factors that influence women entrepreneurs in their involvement, achievement, and failure in business has revealed that 38.6 per cent of the respondents stated that they faced some problems in hiring the right employees. Figure 2 below summarizes the key findings on digital business challenges which may offer a valuable insight on strategize best practices and policy review for sustaining women entrepreneurial development.

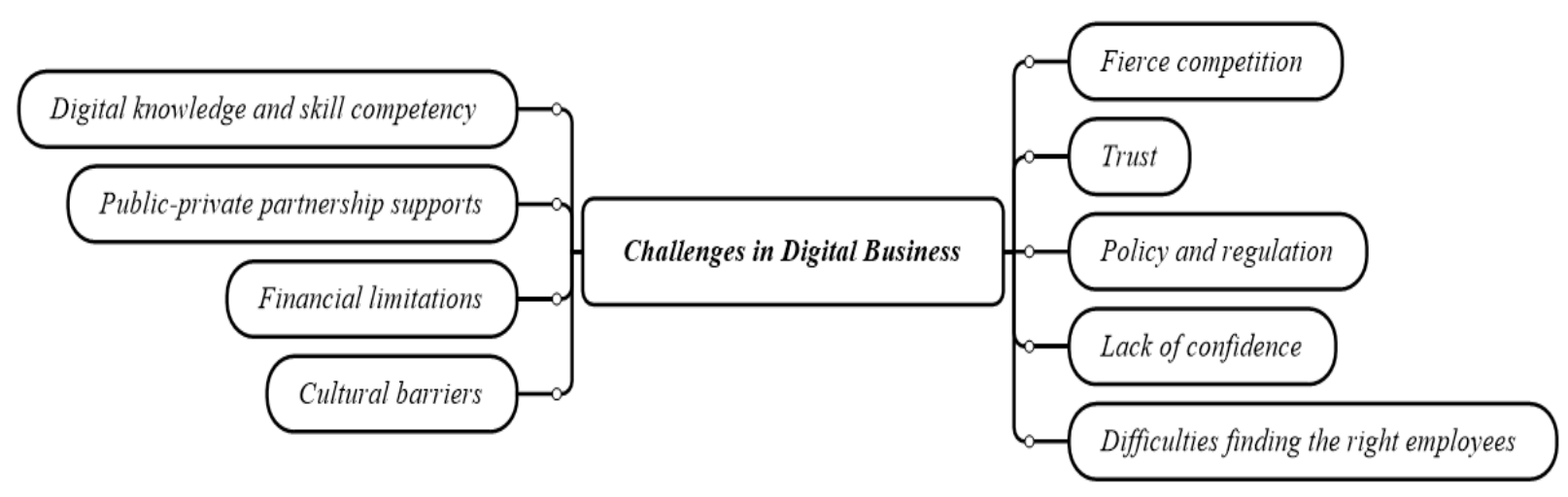

Figure 2: Mapping Digital Business Challenges

\section{Discussion}

Based on the review above, it is evident that women participation in business activities plays a crucial role in both social and economic developments. The rapid advancement of technology has created more freedom for women to run business in the most efficient and productive ways alongside maximising the potential income creation for themselves and family. Proper management of the challenges is the key factor to allow women to be strongly adaptable in digital-driven businesses. Despite the abundance of great opportunities in digital business, entrepreneurs are also susceptible to the danger of cybercriminals (Leţia, 2014). Women entrepreneurs are more likely to be affected by digital threats since their online visibility can have negative psychological effects upon women sensitive issues, such as pornography, trafficking, violence against women, and censorship (Michota, 2013).

The negative circumstances that hamper women's involvement in digital technology must be resolved by means of enforced regulations, including concerns over security and privacy of data that might impede the process of digital business. A study that was performed on a group of women-owned businesses in Nigeria has revealed that ICT literacy had a significant effect on the relationship between ICT adoption and performance of women-owned SMEs in 
Southwestern Nigeria (Omiunu, 2019). This research also emphasised on the importance of conducting a well-structured ICT training programme by government authorities and private agencies in creating a more sustained environment for the business of women entrepreneurs. Business owners and managers are also prompted to deal with digital complexity, aligned with business transformation and growth (Reynolds and Yetton, 2015). In dealing with the technological complexities, it has been proposed that the establishment of womencentralised incubator might bring positive effects to the sustainability of women-owned business (Kapinga et al., 2018).

Furthermore, ensuring a vast availability of financial assistance is another key challenge to make women adaptable to digital business in this modern world. The empowerment of women through income-generating capacity can be achieved successfully through an adequate and successful financial programme (Krishnan et al., 2017; Islam, 2011). For example, the financial assistance programme in Malaysia that is known as Amanah Ikhtiar Malaysia (AIM) targets low-income households has been implemented successfully. In correlation with the objective of microfinance establishment, the programme has recorded an impressive result which has helped the low-income group generate higher income from business activities (Al-Mamun and Mazumder, 2015). The financing arrangement which has a similar aspiration with the success story of Grameen Bank has led to a noticeable cut in poverty figures of the underserved group, namely the rural citizens and women. The relevance of this financing arrangement to facilitate women's participation in digital business can be a convincing strategy to be replicated, which otherwise not possible through standard financing practices.

Moreover, the empowerment of women through digital entrepreneurship persists to be a practical platform to curb family-related issues. The government's effort in targeting women to engage in income-generating activities in order to tackle poverty issue at micro-level is considered as a viable strategy to empower women, particularly those living in rural areas (Aysha et al., 2018). Nonetheless, it is significant to note that this economic burden on women may likely cause a great sacrifice to the family members. Women have traditionally served as a homemaker and typically involve in child-rearing duties and house chores. Unless cultural reforms pertaining to barriers over men-women traditional roles in society are tackled efficiently, the benefits of digital business transformation will be attained through the empowerment of women.

\section{Conclusion}

The recent trending of digitalisation in human's lifestyle has impacted the way in which businesses are progressing. This emerging phenomenon has also captured a considerable interest of researchers towards understanding its underlying causes and effects. The paper has deduced that the empowerment of women can be achieved not only through owning a business, but also to embark on digital initiatives. These motives can create micro and macro opportunities for national leaders to strengthen the social and economic roles of women for the betterment of the traditionally underserved community.

Hence, understanding the challenges that lie ahead is the key to experience success from such a great breakthrough in policy development. These challenges, whether internal or external factors of the women require strategic attention and full support from policymakers and effective actions by the regulators. The timely and appropriate management of these challenges acts as the critical success factor in conducting the mission of empowering womenowned business in the era of rapid digital transformation. 
It is suggested that perhaps, this agenda might be the most effective solution to major social and economic problems. Nonetheless, it is not claimed that the current paper has presented a complete review of the relevant empirical works from worldwide research. The coverage of this review has at least provided a sufficient and clear picture to further facilitate academic inquiry to the current progress of the topic concerned. Forthcoming studies can be conducted by adopting a scientific and systematic approach to explore and develop a comprehensive framework to understand the relevant issues including the impact of digital connectivity, digital adoption, and usage towards the economic performance of women-owned businesses.

\section{References}

Abdul Razak, N., \& Amran, S. N. A. (2016). Development of Women Netpreneurs for Digital Economy [Paper Presentation]. 1st International Conference On Women And Children Legal And Social Issues, Subang, Malaysia.

Abdul Razak, N., \& Jah, J. A. N. (2016). Online Writing Strategies in Social Media For Women Entrepreneurs, Journal Of Human Sciences And Humanities, 11(2), 497-515.

Alam, S. S., \& Jani, M. F. M. (2011). An empirical study of success factors of women entrepreneurs in Southern Region in Malaysia, International Journal of Economics and Finance, 3(2), 166-175.

Al-Mamun, A., \& Mazumder M. N. H. (2015). Impact of Microcredit on Income, Poverty, and Economic Vulnerability in Peninsular Malaysia. Development in Practice 25(3), 333-46. https://doi/full/10.1080/09614524.2015.1019339

Anisiobi A. L., Uchenna, O. I., \& Karubi, N. P. (2014). Women Entrepreneurship in Malaysia: An empirical Journal of Humanities Social Sciences and Education, 1(4), 48-58.

Asia Pacific Women's Information Network Center. (2018). Case Studies of Successful Women Entrepreneurs in the ICT Industry in 21 APEC Economies. APEC Policy Partnership on Women and the Economy.

Asian Development Bank and The Asia Foundation Report. (2018). Case Studies from the Asian Development Bank. Asian Development Bank and The Asia Foundation. http://dx.doi.org/10.22617/TCS 189585-2

Aysha, A., Nobaya, A., Ai, M., Wj, W. M., Bz, D., \& Mi, M. (2018). Empowerment Scenario of Rural Women through Income Generating Activities in Bangladesh. Arts and Social Sciences Journal, 9(5). https://doi.org/10.4172/2151-6200.1000414

Beninger, S., Ajjan, H., \& Mostafa, R., \& Crittenden, V. (2016). A road to empowerment: social media use by women entrepreneurs in Egypt. International Journal of Entrepreneurship and Small Business, 27(2/3), 308. https://doi.org/10.1504/IJESB.2016.073987

Cesaroni, F. M., Demartini, P., \& Paoloni, P. (2017). Women in business and social media: Implications for female entrepreneurship in emerging countries. African Journal of Business Management, 11(14), 316-326.

Chatterjee, S., Gupta, S. D., \& Upadhyay, P. (2020). Technology Adoption and Entrepreneurial Orientation for Rural Women: Evidence from India. Technological Forecasting and Social Change, 160, 120236. https://doi.org/10.1016/j.techfore.2020.120236

Everson, C. (2019). Female Entrepreneurship Is Changing the Modern Workforce. Adweek. https://www.adweek.com/brand-marketing/female-entrepreneurship-is-changing-themodern-workforce/

Fuad, N., Bohari, A. M., \& Hin, C. W. (2011). Women Entrepreneurs in the ICT-Related Business in Malaysia: A Demographic Survey. International Journal of Business and Management, 6 (10). 
Guidant. (2019). 2019 Small Business Trends. https://www.guidantfinancial.com/smallbusiness-trends/

Happyson, B., Pinninti, S., Mhlanga, S. P., Ndwandwe, L., Nkambule, N., \& Sbisi, P. (2018). Challenges Faced by Women Entrepreneurs in Small and Medium Enterprises in Swaziland. Indian Journal of Commerce \& Management Studies, 9(1), 85-95.

Hashim, F. (2012). Challenges for the Internationalization of SMEs and the Role of Government: The Case of Malaysia. Journal of International Business and Economy, 13(1), 97-122.

Hashim, F., Amir, Z., \& Abdul Razak, N. (2011). Empowering rural women entrepreneurs with ICT skills: an impact study. Procedia Social and Behavioral Sciences, 15, 3369-3373.

Hossain, J., Jahangir, N., \& Ahad, M. N. (2018). A Study on Female Entrepreneurs in Malaysia. Business Ethics and Leadership, 2(3), 67-73. https://doi.org/10.21272/bel.2(3).6773.2018

Ilhamamie, A. G. A., Arni, S. B., Rosmawani, C. H., \& Al Banna, H. M. (2014). Challenges of Muslim women entrepreneurs in Malaysia SMEs. International journal of innovation, management and technology, 5(6), 428-433.

Isaga, N. (2019), Start-up motives and challenges facing female entrepreneurs in Tanzania, International Journal of Gender and Entrepreneurship, 11(2), 102-119. https://doi.org/10.1108/IJGE-02-2018-0010

Islam, M. (2011). Rural Women's Empowerment through Self-Income Generating Activities : A Study on NGOs Credit Programs in Bangladesh. Journal of Global Citizenship \& Equity Education, 1(1), 96-123.

Jones, N., Borgman, R., \& Ulusoy, E. (2015). Impact of social media on small businesses. Journal of Small Business and Enterprise Development, 22(4), 611-632. https://doi.org/10.1108/JSBED-09-2013-0133

Kamberidou, I. (2020). "Distinguished" Women Entrepreneurs in The Digital Economy and The Multitasking Whirlpool". Journal of Innovation and Entrepreneurship, 9(3). https://doi.org/10.1186/s13731-020-0114-y

Kazimoto, P. (2014). Assessment of Challenges facing SMEs towards International Marketing Standards: a Case Study of Arusha Region Tanzania. International Journal of Academic Research in Accounting, Finance and Management Sciences, 4(2), 303-311.

Komunte, M. (2015). Usage of Mobile Technology in Women Entrepreneurs: A Case Study of Uganda. The African Journal of Information Systems, 7(3).

Krieger-Boden, C., \& Sorgner, A. (2018). Labor market opportunities for women in the digital age. Economics, 12(1), 20180028. https://doi.org/10.5018/economics-ejournal.ja.201828

Krishnan, N. V. H., Sivramkrishna, S., \& Warrier, U. (2017). Women Empowerment Through Enhancement of Income Generation and Decision. Indian Journal of Commerce \& Management Studies, 8, 1-6.

Leţia, A. (2014). Challenges of Business Digital Environment. Quality - Access to Success, 15, 111-15.

Maier, S., \& Nair-Reichert, U. (2008). Empowering Women Through ICT-Based Business Initiatives: An Overview of Best Practices in E-Commerce/E-Retailing Projects. Information Technologies and International Development, 4, 43-60. https://doi.org/10.1162/itid.2008.00007

Malik, I. S. B. A., Chan, V., \& Chan, C. (2021). The Determinants Factors of Womenpreneurship Performances in Low Economic Class : An Evidence from Melaka. 
International Journal of Entrepreneurship, Business and Creative Economy, 1(1), 25-38. https://doi.org/10.31098/ijebce.v1i1.423

Maura, M. A., Caren, C., \& Richard, T. H. (2018). "To boldly go where no [man] has gone before" - Institutional voids and the development of women's digital entrepreneurship. Technological Forecasting and Social Change,146, 912-922. https://doi.org/10.1016/j.techfore.2018.07.051

Merve, G., \& Burcu, O. (2015). A Fact or an Illusion: Effective Social Media usage of Female Entrepreneurs, Procedia - Social and Behavioral Sciences,195(3), 293-300.

Michota, A. (2013). Digital security concerns and threats facing women entrepreneurs. Journal Innovation Entrepreneurship, 2, 7. https://doi.org/10.1186/2192-5372-2-7

Mishra, V. (2017). Gendering the G20: Empowering Women in the Digital Age. Observer Research Foundation (ORF), 186, 1-12.

Hamdan, M. A. R., \& Hassan, M. M. (2018). Faktor Penglibatan Dan Cabaran Wanita Melayu Dalam Keusahawanan Di Malaysia [Paper Presentation]. Tun Fatimah Hashim Women Lead Conference 2018 (TFHWLC 2018), Putrajaya, Malaysia.

Oggero, N., Rossi, M. C., \& Ughetto, E. (2020). Entrepreneurial spirits in women and men. The role of financial literacy and digital skills. Small Business Economics, 55(2), 313327. https://doi.org/10.1007/s11187-019-00299-7

Pergelova, A., Manolova, T., Simeonova-Ganeva, R., \& Yordanova, D. (2019).cDemocratizing Entrepreneurship? Digital Technologies and the Internationalization of Female-Led SMEs. Journal of Small Business Management, 57(1), 14-39. https://doi.org/10.1111/jsbm.12494

Prokopenko, O., Shmorgun, L., Kushniruk, V., Prokopenko, M., Slatvinska, M., \& Huliaieva, L. (2020). Business Process Efficiency in a Digital Economy. International Journal of Management (IJM), 11 (3), 122-132.

Raman, K., Anantharaman, R. N., \& Jayasingam, S. (2008). Motivational Factors Affecting Entrepreneurial Decision: A Comparison between Malaysian Women Entrepreneurs and Women Non Entrepreneurs. Communications of the IBIMA, 2, 85-89.

Reynolds, P., \& Yetton, P. (2015). Aligning Business and IT Strategies in Multi-business Organizations. Journal of Information Technology, 30(2), 101-118. https://doi.org/10.1057/jit.2015.1

Shmailan, A. B. (2016). Compare the Characteristics of Male and Female Entrepreneurs as Explorative Study. Journal of Entrepreneurship and Organization Management, 5, 203. https://doi.org/10.4172/2169-026X.1000203

Simanjuntak, M., Putri, N. E., Yuliati, L. N., \& Sabri, M. F. (2020). Enhancing Customer Retention Using Customer Relationship Management Approach in Car Loan Business. Cogent Business \& Management, 7(1), 1738200.

Smith, R. M., Sardeshmukh, S. R., \& Combs, G. M. (2016). Understanding gender, creativity, and entrepreneurial intentions. Education + Training, 58(3), 263-282. https://doi.org/10.1108/ET-06-2015-0044

Tehseen, S., Muneeb, D., Mahmoud, A. B., Hack-Polay, D., Yan, Y. H., \& Nawaz, F. (2021). SMEs in the digital business sector: examining six theories about digital SME success. In R. Ho, A. Ng, \& M. Nourallah (Eds.), Impact of Globalization and Advanced Technologies on Online Business Models. IGI Global.

Teoh, W. M. Y., \& Chong, S. C. (2014). Towards strengthening the development of women entrepreneurship in Malaysia. Gender in Management, An International Journal, 29(7),432-453. https://doi.org/10.1108/GM-10-2013-0122 
Thuaibah, A. B., Azlah, M. A., Omar, R., Som, H., \& Muktar, S. N. (2007). Women's Involvement In Entrepreneurship In Johor: A Study About Critical Factors In Achievement And Failure In Handling Business. Universiti Teknologi Malaysia. http://eprints.utm.my/id/eprint/5803/1/75087.pdf

United States Census Bureau. (2018). Census Bureau Announces New 2017 Annual Business Survey [Press Release]. https://www.census.gov/newsroom/pressreleases/2018/annual-business-survey.html

Utusan Malaysia. (2019). Peniaga Online Tertekan Berdepan Pelbagai Cabaran. https://www.utusan.com.my/berita/nasional/peniaga-online-tertekan-berdepanpelbagai-cabaran-1.837427

Victoria L., William, C. F., \& Crittenden, H. (2019). Empowering women micro-entrepreneurs in emerging economies: The role of information communications technology. Journal of Business Research, 98 (5), 191-203.

Wahid, N. A., Aziz, N. N. A., Ishak, M., \& Hussin, A. (2021). The Critical Success Factors of Business Growth among Women Entrepreneurs in Malaysia: A Qualitative Approach. International Journal of Academic Research in Business and Social Sciences, 11(9), 1699-1713. https://doi.org/10.6007/IJARBSS/v11-i9/10861

Wally, E., \& Koshy, S. (2014). The use of Instagram as a marketing tool by Emirati female entrepreneurs: an exploratory study [Paper Presentation]. 29th International Business Research Conference, World Business Institute Australia, Australia.

Xavier, S. R., Ahmad, S. Z., Perumal, S., Nor, M. L., \& Mohan, J. C. (2011). The transition from corporate careers to business ownership: The case of women entrepreneurs in Malaysia. International Journal of Business Administration, 2(3), 148-159. 